\title{
Analysis of Effect of GRDP (Gross Regional Domestic Product) Per Capita, Inequality Distribution Income, Unemployment and HDI (Human Development Index) on Poverty
}

\author{
Murbanto Sinaga \\ Faculty of Economics and Business, Universitas Sumatera Utara, Indonesia \\ murbanto_sinaga@yahoo.com
}

\begin{abstract}
This study aims to examine the effect of GRDP per capita, inequality of income distribution, unemployment, and HDI on poverty. The dependent variable of the study is poverty, while the independent variable used is the GRDP per capita, income distribution inequality, unemployment, and HDI. This research was conducted in Batu Bara Regency and Medan City in the 2004-2018 period. The research data were obtained by accessing the Central Statistics Agency (BPS) website. The method of data analysis uses multiple linear regression analysis. The analysis shows that unemployment is negative and significant towards poverty. Meanwhile, per capita GRDP, income distribution inequality, and HDI have a negative and not significant effect on poverty. This study also found interesting findings, that the equality that occurred in Batu Bara Regency and Medan City was equalization in poverty not equality in welfare. Then, unemployment in Batu Bara Regency and Medan City is likely to be dominated by residents in the upper middle class who have completed Education at the senior secondary level and above.
\end{abstract}

Keywords

poverty, inequality of income distribution; unemployment; $\mathrm{HI}$

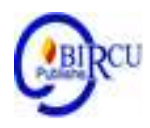

\section{Introduction}

Poverty is still a major problem in the economy today. This poverty problem will continue to be a subject of study, as long as economic development goals are still not achieved. Although many studies have been done, but the standard formula for overcoming the problem of poverty has not yet been found. This is mainly because poverty is influenced by many factors. Some previous studies have found that GDP per capita, income distribution inequality, unemployment and HDI have a significant effect on poverty (Chandra et al., 2010; Fadlillah et al., 2016; Wiguna, 2013; Irawan and Arka, 2015; Akhmad et al., 2018; Yacoub, 2012; Putra and Arka, 2018; Cholili, 2014; Prasetyoningrum and Sukmawati, 2018).

Batu Bara Regency and Medan City are two regions in North Sumatra province that also face the challenge of poverty alleviation. From 2016 to 2018, the poverty rate in Batu Bara District has continued to increase. During this period, the poverty rate in Batu Bara Regency was 12.24 in 2016; 12.48 in 2017; and 12.57 in 2018. On the other hand, in 2018, the GRDP per capita of Batu Bara Regency is actually very high, amounting to Rp. $55,687,755$. Inequality of income distribution is also relatively low, it can be seen through the Gini Ratio value of 0.2335. With these conditions, the poverty level in Batu Bara District should have dropped significantly. 
When viewed from the side of the unemployment rate too, the open unemployment rate in Batu Bara in 2018 is still relatively low, at 5.39\%, still below Medan City (8.25\%) North Sumatra (5.56\%). This means that there are other factors that cause poverty levels in Batu Bara District to remain high even though the GDP per capita is very high and even exceeds the GDP per capita of North Sumatra (Rp. 35,570,705), the income distribution is relatively even, and the unemployment rate is low. This phenomenon needs to be studied further in order to find out the root problems behind this phenomenon.

\section{Review of Literatures}

Research Chandra et al. (2010) and Fadlillah et al. (2016) found that per capita income had a negative and significant effect on poverty. Per capita income is a reflection of the level of welfare of each population. So if per capita income increases it also indicates an increase in welfare. Wiguna (2013) found that the GRDP had a negative and significant effect on poverty in Central Java. Meanwhile, Irawan and Arka's (2015) research found that GRDP per capita had a negative and significant effect on the number of poor people.

Inequality of income distribution also affects poverty levels. Gini ratio can indicate the level of inequality of income distribution in a region. A lower Gini value indicates higher equity. The results of the research of Akhmad et al. (2018) shows that the Gini ratio has a positive and significant effect on increasing poverty, which means that any increase in income inequality can lead to an increase in poverty.

Unemployment is one of the sources of poverty. Unemployment causes a person to lose a source of income, so someone who is unemployed is threatened to fall into poverty, because they do not have the ability to meet their basic needs. The bad effect of unemployment is reducing people's income which in turn reduces the level of prosperity one has achieved (Sukirno, 2004). Yacoub (2012) found that the unemployment rate had a significant effect on the poverty rate of districts / cities in West Kalimantan Province. While the results of Putra and Arka's research (2018) show that the level of open unemployment has a positive and significant effect on poverty levels.

One indicator of the success of economic development is the Human Development Index (HDI). HDI describes the achievements of economic development in the development of human resources. Arsyad (2010) suggested that one of the strategies to reduce poverty is the development of human resources. Some studies have found that HDI has a significant effect on poverty. Research by Cholili (2014), Prasetyoningrum and Sukmawati (2018), and research by Fadlillah et al. (2016) found that HDI had a negative and significant effect on poverty. 


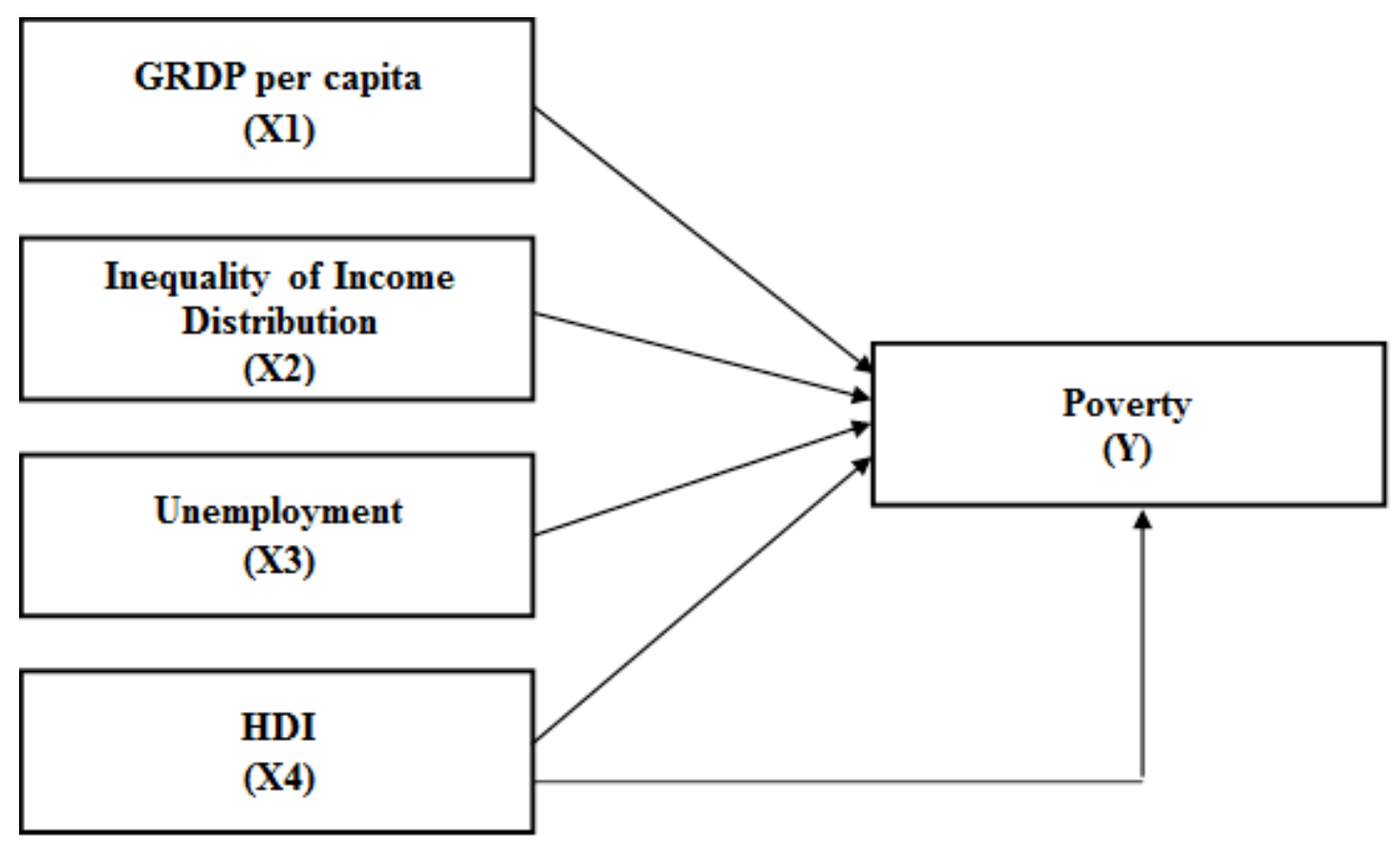

Figure 1. Conceptual Framework

Based on the description and conceptual framework of the research that has been made, the research hypothesis is:

1. GRDP per capita has a negative effect on poverty.

2. Inequality of income distribution has a positive effect on poverty.

3. Unemployment has a positive effect on poverty.

4. HDI has a negative effect on poverty.

\section{Research Methods}

This research is quantitative descriptive. The research focuses on analyzing the effect of GRDP per capita, inequality of income distribution, unemployment and HDI on poverty. The main variables studied were poverty, while the independent variables of the study were GRDP per capita, income distribution inequality, unemployment and HDI. Inequality in income distribution is measured using the Gini ratio, while unemployment is measured using the Open Unemployment Rate. The results of this analysis are expected to be able to uncover the phenomena that occur in Batu Bara District and Medan City as described in the introduction.

This research was conducted in Batu Bara Regency and Medan City in the 2004-2018 periods. The research data includes per capita GRDP data, income distribution inequality, unemployment, HDI and poverty obtained from the Central Statistics Agency (BPS) website.

The data analysis process is carried out in stages. Data analysis begins with testing classic assumptions to ensure the regression model meets the BLUE (Best Linear Unlock Estimator) assumption. Classical assumptions testing include testing for normality, autocorrelation testing, multicollinearity testing, and heterokedasticity testing. The normality test uses the Kolmogorov-Smirnov Test, the autocorrelation test uses the Run Test, the multicollinearity test uses the VIF (Variance Inflation Factor) value, and the heterokedasticity test uses the Glejser test. After testing classic assumptions, the next step is testing hypotheses. 
The research regression model that will be tested is as follows:

$$
Y=\alpha-\beta_{1} X_{1}+\beta_{2} X_{2}+\beta_{3} X_{3}-\beta_{4} X_{4}+e
$$

Keterangan:

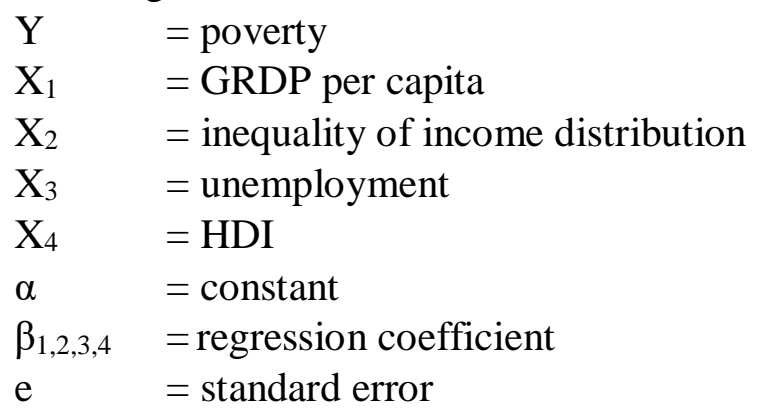

\section{Results and Discussion}

\subsection{Results}

a. The Classical Assumption Test

The classical assumption tests include normality test, autocorrelation test, multicollinearity test, and heterokedasticity test.

Table 1. Normality Test Results

One-Sample Kolmogorov-Smirnov Test

\begin{tabular}{|c|c|c|}
\hline & & $\begin{array}{l}\text { Unstandardized } \\
\text { Residual }\end{array}$ \\
\hline $\mathrm{N}$ & & 30 \\
\hline \multirow[t]{2}{*}{ Normal Parameters ${ }^{\mathrm{a}, \mathrm{b}}$} & Mean & .0000000 \\
\hline & Std. Deviation & 1.54212217 \\
\hline \multirow[t]{3}{*}{ Most Extreme Differences } & Absolute & .113 \\
\hline & Positive & .113 \\
\hline & Negative & -.078 \\
\hline Kolmogorov-Smirnov Z & & .618 \\
\hline Asymp. Sig. (2-tailed) & & .840 \\
\hline
\end{tabular}

Table 1 shows the results of normality testing. Based on Table 1, the Asymp Sig. (2tailed) value is known of 0.840 . This value is greater than 0.05 . Thus, it can be concluded that the research data are normally distributed. 
Table 2. Autocorrelation Test Results

\begin{tabular}{lr}
\multicolumn{2}{c}{ Runs Test } \\
\hline & $\begin{array}{c}\text { Unstandardized } \\
\text { Residual }\end{array}$ \\
\hline Test Value $^{\mathrm{a}}$ & .04256 \\
Cases < Test Value & 15 \\
Cases >= Test Value & 15 \\
Total Cases & 30 \\
Number of Runs & 12 \\
Z & -1.301 \\
Asymp. Sig. (2-tailed) & .193 \\
\hline a. Median &
\end{tabular}

Table 2 shows the results of autocorrelation testing. Based on Table 2, the Asymp Sig. (2-tailed) value is known of 0.193 . This value is greater than 0.05 , which indicates that the research model is free from multicollinearity problems.

Table 3. Multicollinearity and Heterokedasticity Test Results

\begin{tabular}{lcc}
\hline \multicolumn{1}{c}{ Variabel } & VIF & Sig. \\
\hline GRDP per capita & 2.103 & 0.227 \\
Inequality of income distribution & 2.673 & 0.968 \\
Unemployment & 2.440 & 0.513 \\
HDI & 2.892 & 0.487 \\
\hline
\end{tabular}

Table 3 shows the results of multicollinearity and heterokedasticity testing. From this table, it is known that VIF value $<10$ and sig. value each variable is greater than 0.05 . This shows that the research model is free from multicollinearity and heterokedasticity problems.

\section{b. Hypothesis Testing} tables.

The results of the multiple linear regression analysis are presented in the following

Table 4. Determination Coefficient Test Results Model Summary ${ }^{\text {b }}$

\begin{tabular}{|c|c|c|c|c|}
\hline Model & $\mathrm{R}$ & R Square & $\begin{array}{l}\text { Adjusted R } \\
\text { Square }\end{array}$ & $\begin{array}{l}\text { Std. Error of } \\
\text { the Estimate }\end{array}$ \\
\hline 1 & $.769^{\mathrm{a}}$ & .592 & .527 & 1.66092 \\
\hline \multicolumn{5}{|c|}{$\begin{array}{l}\text { a. Predictors: (Constant), GRDP per capita, inequality of } \\
\text { income distribution, unemployment, HDI }\end{array}$} \\
\hline b. Depe & nt Varia & ple: Poverty & & \\
\hline
\end{tabular}

The coefficient of determination shows the amount of variation in the dependent variable that can be explained by the independent variable. Table 4 shows the Adjusted $\mathrm{R}$ Square value of 0.527 . That is, GDP per capita, income distribution inequality, unemployment and HDI are able to explain the poverty variation of $52.7 \%$, while the rest is explained by other variables not contained in the research model. 
Table 5. Simultaneous Significance Test Results (F Test)

ANOVA $^{b}$

\begin{tabular}{llrrrrr}
\hline Model & & Sum of Squares & df & Mean Square & F & Sig. \\
\hline 1 & Regression & 100.084 & 4 & 25.021 & 9.070 & $.000^{\mathrm{a}}$ \\
& Residual & 68.966 & 25 & 2.759 & & \\
& Total & 169.050 & 29 & & & \\
\end{tabular}

a. Predictors: (Constant), GRDP per capita, inequality of income distribution, unemployment, HDI

b. Dependent Variable: Poverty

F test aims to test the effect of independent variables on the dependent variable simultaneously. The independent variable is stated to have simultaneous effect on the dependent variable if the probability of significance of the $F$ test is less than 0.05. Based on Table 5, it is known that the probability of significance of the $\mathrm{F}$ test is 0,000 . This value is smaller than 0.05 , so it can be concluded that the GDP per capita, income distribution inequality, unemployment and HDI simultaneously affect poverty.

Table 6. Results of Partial Significance Tests (t Test)

Coefficients $^{\mathrm{a}}$

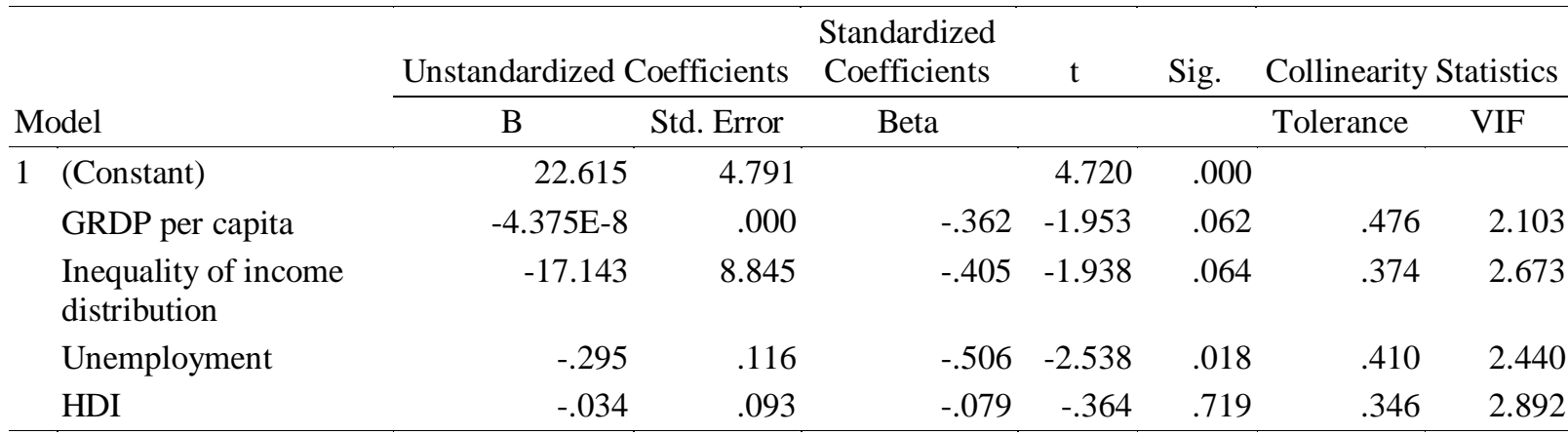

a. Dependent Variable: Poverty

Based on Table 6, the regression equation can be written as follows:

$$
Y=22,615-0,0000000437 X_{1}-17,143 X_{2}-0,295 X_{3}-0,034 X_{4}
$$

The equation can be explained as follows:

1. Constant of 22,615 indicates that if the GRDP per Capita, Inequality of income distribution, Unemployment and HDI is 0, the poverty rate in Batu Bara Regency and Medan City is $22.62 \%$.

2. The GDRP per capita regression coefficient per capita of -0.0000000437 implies that if the GRDP per capita rises by one rupiah and other variables are of a fixed value, poverty will decrease by $0.0000000437 \%$.

3. Inequality of income distribution regression coefficient of $-17,143$ implies that if the income distribution inequality rises by one unit and other variables are of a fixed value, then poverty will decrease by $17.143 \%$. 
4. The unemployment regression coefficient of -0.295 means that if unemployment rises by $1 \%$ and other variables are of a fixed value, poverty will decrease by $0.295 \%$.

5. HDI regression coefficient of -0.034 implies that if the HDI rises by one unit and the other variables are fixed, then poverty will decrease by $0.034 \%$.

Table 6 presents the results of the partial significance test or $t$ test. T test aims to examine the effect of independent variables on the dependent variable partially. The independent variable is stated to have a significant effect on the dependent variable if the significance value of the t test significance is less than 0.05 . From Table 6 , it is known that the probability of GRDP per capita significance is 0.062 and has a regression coefficient that is negative. The significance value of the probability is greater than 0.05 . This shows that GDP per capita has a negative and not significant effect on poverty.

The significance value of the income distribution inequality variable is 0.064 with a regression coefficient marked negative. The significance value of the probability is greater than 0.05 . Therefore, it can be concluded that inequality in income distribution has a negative and not significant effect on poverty.

Unemployment variable has a significance probability value of 0.018 and the regression coefficient is negative. The significance value of the probability is smaller than 0.05 . Thus, it can be concluded that unemployment has a negative and significant effect on poverty.

The significance value of the HDI variable is 0.719 and the regression coefficient is negative. The significance value of the probability is greater than 0.05 . Thus, it can be concluded that HDI has a negative and not significant effect on poverty.

\subsection{Discussion}

The results of the analysis show that per capita GRDP has a negative but not significant effect on poverty in Batu Bara District and Medan City. The results of this study are consistent with the initial assumption that the GRDP has a negative effect on poverty, although the effect is not significant.

This study found that inequality in income distribution had a negative but not significant effect on poverty in Batu Bara District and Medan City. This finding is not in accordance with the initial assumption, that the inequality of income distribution has a positive effect on poverty. The negative relationship between income distribution inequalities with poverty implies that an increase in income distribution inequality will be followed by a reduction in poverty levels. This finding is a solution to the research phenomenon, that the equality that occurs in Batu Bara Regency and Medan City is equalization in poverty, not even distribution in welfare. This means that the income gap between the residents of Batu Bara Regency and Medan City is indeed classified as low or relatively evenly distributed, but the problem lies precisely in the level of income of the population classified as below the poverty line. Therefore, the equality that occurs is equality in poverty. In addition, this finding also shows that there are a handful of rich people who are getting richer in Batu Bara District and Medan City. A handful of these rich people control most of the benefits of economic development, while the majority of the population only enjoys a small portion of the benefits of economic development. As a result, high GDP per capita does not contribute significantly to poverty reduction. As is known, Medan City and Batu Bara Regency are regions that have the highest per capita GRDP in North Sumatra with poverty rates that are also relatively high. 
Unemployment was found to have a negative and significant effect on poverty in Batu Bara District and Medan City. This finding is not in line with initial estimates. In general, unemployment has a positive relationship with poverty. A decrease in the unemployment rate should contribute to a reduction in poverty, because a decrease in unemployment means that people who are not earning and threatened unable to meet their basic needs have been reduced. However, the decline in the unemployment rate is not always followed by a decrease in the poverty rate, or vice versa. As the findings in this study, an increase in unemployment actually affects the reduction in poverty levels. One reason for this is the extended family factor. That is, the concern between relatives or neighbors is manifested in the attitude of mutual help to help. Families who already have jobs want to support their families who are either unemployed or unemployed. In addition, it is likely that the population classified as unemployed in Batu Bara District and Medan City are dominated by residents in the upper middle class who have completed high school education and above. These unemployed residents have no income, but do not live poor because all their needs are borne by their families. This familial culture is still thick in the middle of Indonesian society in general and the people of Batu Bara Regency and Medan City in particular. Thus, the cultural factors of an area also play an important role in moderating the relationship between unemployment and poverty.

HDI was found to have a negative but not significant effect. That is, an increase in HDI will be followed by a reduction in poverty levels. This finding is in line with initial allegations although its contribution is not significant.

\section{Conclusion}

This study aims to examine the effect of per capita GRDP, inequality of income distribution, unemployment and HDI on poverty. Based on the results of the analysis that has been done, it can be concluded that per capita GRDP, income distribution inequality and HDI have a negative and not significant effect on poverty. Meanwhile, Unemployment has a negative and significant effect on poverty. Per capita GRDP, inequality of income distribution, unemployment and HDI simultaneously affect poverty.

There are two interesting findings from the results of this study. First, the equality that occurs in Batu Bara Regency and Medan City is equal distribution in poverty, not equality in welfare. Second, unemployment in Batu Bara District and Medan City is likely to be dominated by people in the upper middle class who have completed Education at the senior secondary level and above.

\section{References}

Akhmad, Alyas, dan Amir (2018). The Effect of Economic Growth and Income Inequality on Poverty in Indonesia. IOSR Journal of Economics and Finance. Volume 9, Issue 4 Ver. II. PP 20-26.

Amal, B. K. 2018. The Exploring of Marxism Regarding The Poverty Sustainability in Kampung Nelayan Seberang, Belawan, Indonesia. Budapest International Research and Critics Institute-Journal (BIRCI-Journal) (1): 79-92

Arsyad, L. 2010. Ekonomi Pembangunan. Edisi Kelima. STIM YKPN, Yogyakarta. 
Chandra, A. (2010). Keterkaitan Pertumbuhan Ekonomi dan Pendapatan per Kapita terhadap Kemiskinan di Jawa Tengah Tahun 2003-2010. Jurnal Media Ekonomi \& Teknologi Informasi. Vol. 20 No.2.

Cholili, F.M. (2014). Analisis Pengaruh Pengangguran, PDRB dan IPM terhadap Jumlah Penduduk Miskin (studi kasus: 33 Provinsi di Indonesia). Jurnal Ilmu Ekonomi, Fakultas Ekonomi dan Bisnis Universitas Brawijaya. Vol. 2. No. 1

Fadlillah, Sukiman, dan Dewi. (2016). Analisis Pengaruh Pendapatan Per Kapita, Tingkat Pengangguran, Ipm Dan Pertumbuhan Penduduk Terhadap Kemiskinan Di Jawa Tengah Tahun 2009-2013. Eko-Regional. Vol. 11, No. 1.

Harahap, E. S., Maipita, I. Rahmadana, M. F. 2020. Determinant Analysis of Education Inequalities in Indonesia. Budapest International Research and Critics Institute-Journal (BIRCI-Journal) (3): 1067-1082.

Lubis, R., Phill, I. A., and Baiduri, R. Survival Strategy for Lokan Seekers in Paya Pasir Village, Kec. Marelan, Medan, Indonesia. Budapest International Research and Critics Institute-Journal (BIRCI-Journal) (2): 293-303.

Prasetyoningrum, A. K. dan U. S. Sukmawati. (2018). Analisis Pengaruh Indeks Pembangunan Manusia (IPM), Pertumbuhan Ekonomi dan Pengagguran Terhadap Kemiskinan di Indonesia. Equilibrium: Jurnal Ekonomi Syariah. Volume 6, Nomor 2, pp. $217-240$.

Putra, I. Komang. A., dan S. Arka. (2018). Analisis Pengaruh Tingkat Pengangguran Terbuka, Kesempatan Kerja, dan Tingkat Pendidikan terhadap Tingkat Kemiskinan pada Kabupaten/Kota di Provinsi Bali. E-Jurnal Ekonomi Pembangunan Universitas Udayana, Vol. 7, No. 3. Pp. 416-444.

Sukirno, S. (2004). Makro Ekonomi Teori Pengantar. Jakarta: Raja Grafindo Persada.

Wiguna, V. I. (2013). Analisis Pengaruh PDRB, Pendidikan dan Pengangguran terhadap Kemiskinan di Provinsi Jawa Tengah Tahun 2005-2010. Jurnal Ilmu Ekonomi, Fakultas Ekonomi dan Bisnis Universitas Brawijaya. Vol. 1. No. 2

Wirawan, I. Made. T., dan S. Arka. (2015). Analisis Pengaruh Pendidikan, PDRB per Kapita dan Tingkat Pengangguran terhadap Jumlah Penduduk Miskin Provinsi Bali. E-Jurnal Ekonomi Pembangunan Universitas Udayana. Vol. 4, no.5

Yarcoub, Y. (2012). Pengaruh Tingkat Pengangguran terhadap Tingkat Kemiskinan Kabupaten/Kota di Provinsi Kalimantan Barat. Jurnal Eksos. Volume 8, Nomor 3, hal $176-185$. 